\title{
The Impact of Lesional Factors on Seizure Outcome Following Lesionectomy as a Surgical Management of Extratemporal Epilepsy, Case Series from a Developing Country and Review of Literature.
}

Amr Ali Hasanain ( $\nabla$ doctor.amrali@gmail.com )

Egypt Ministry of Health and Population

Mohamed Sawan

Egypt Ministry of Health and Population

Ahmed Mohamed Ali

Egypt Ministry of Health and Population

\section{Research}

Keywords: Epilepsy, Extratemporal, Lesional factors, Lesionectomy, Seizure Outcome

Posted Date: July 14th, 2021

DOI: https://doi.org/10.21203/rs.3.rs-685046/v1

License: @ (i) This work is licensed under a Creative Commons Attribution 4.0 International License. Read Full License 


\section{Abstract}

BACKGROUND

Extratemporal lesional epilepsy can be managed with various surgical techniques such as simple lesionectomy or more extensive resections, all of which aim at targeting the epileptogenic zone which is the key for achieving a favorable outcome. This study aimed at evaluating the effectiveness of lesionectomy in the treatment of extra-temporal epilepsy associated with a lesion on radiological imaging, and to show the effect of lesional factors on seizure outcome including the anatomical location, the relation to cerebral parenchyma, the extent of surgical excision and the histopathological nature of the lesion.

\section{METHODS}

A prospective study on 20 patients presenting with focal epilepsy, or focal epilepsy with secondary generalized seizures with evidence of focal lesion in an extratemporal location on MRI. Lesionectomy was done and we used the Engel's classification for seizure outcome.

RESULTS

Lesions were mostly tumors ( $85 \%$ ). The frontal lobe is the most frequent locations (60\%). Low-grade glioma represented $35 \%$ while meningioma represented $45 \%$ of all lesions (both intra-axial and extra-axial). Four patients were lost during follow up (mean 23.31 months). For the remaining 16 patients, 13 cases were tumors (81.25\%). Lesionectomy achieved seizure freedom in $68.75 \%$.

\section{CONCLUSIONS}

In a country with limited resources, lesionectomy is a valid technique for epilepsy surgery as long as the radiological data and the seizure semiology are concordant. Total lesionectomy provides good seizure control when the clinical and radiological data are concordant with seizure semiology, in particular with tumor-related epilepsy. A study comparing postoperative seizure outcome between intra-axial and extra-axial lesions on a larger scale and with a longer follow up period is recommended.

\section{Introduction}

Extratemporal epilepsy is usually harder to manage than temporal lobe epilepsy, the latter being mostly, but not always, related to the amygdalo-hyppocampal complex. In extratemporal lobe epilepsy, the epileptic focus can be located in different anatomical areas such as the frontal lobe, parietal lobe or occipital lobe. Many pathological conditions can cause extra temporal epilepsy such as tumors, hematomas, contusions, gliosis, traumatic scars, etc.[1] Long-term epilepsy associated tumors (LEAT) represent a well-known cause of focal epilepsies.[2] Resection strategies in patients with tumor-related epilepsy vary from lesionectomy to larger epilepsy operations with no consensus on optimal approaches.[3] All surgical strategies aim at targeting the epileptogenic zone which is crucial for achieving a favorable outcome. This study aims at evaluating the effectiveness of lesionectomy in the treatment of extra-temporal epilepsy associated with a lesion on radiological imaging. We aimed to show the effect of lesional factors on seizure outcome including the anatomical location, the relation to cerebral parenchyma, the extent of surgical excision and the histopathological nature of the lesion.

\section{Materials And Methods}

We performed a prospective study on series of 20 patients admitted to the Neurosurgery Department, presenting with focal epilepsy, or focal epilepsy with secondary generalized seizures with evidence of focal lesion in an extratemporal location on MRI and clinical semiology of seizures concordant with lateralization provided by the imaging. We excluded temporal lobe focal seizures, multifocal seizures and primary generalized seizures. All procedures performed in this study were in accordance with the ethical standards of the ethical committee of the Neurosurgery Department in our institute. Informed consent was obtained from all individual participants included in the study. A master table of the 20 included patients was created and data were recorded to facilitate result analysis (Table 1 ). 
Table 1

Patients Data

\begin{tabular}{|c|c|c|c|c|c|c|c|c|c|c|c|}
\hline Number & Age & Gender & $\begin{array}{l}\text { Clinical } \\
\text { presentation }\end{array}$ & $\begin{array}{l}\text { Anatomical } \\
\text { location }\end{array}$ & $\begin{array}{l}\text { Extent of } \\
\text { lesionectomy }\end{array}$ & $\begin{array}{l}\text { Relation to } \\
\text { cerebral } \\
\text { parenchyma }\end{array}$ & Histopathology & $\begin{array}{l}\text { Short } \\
\text { Term } \\
\text { Follow } \\
\text { UP in } \\
\text { Months }\end{array}$ & $\begin{array}{l}\text { Short } \\
\text { Term } \\
\text { Follow } \\
\text { UP } \\
\text { Engels' } \\
\text { Class }\end{array}$ & $\begin{array}{l}\text { Long } \\
\text { Term } \\
\text { Follow } \\
\text { UP in } \\
\text { months }\end{array}$ & $\begin{array}{l}\text { Long } \\
\text { Follo' } \\
\text { Engel } \\
\text { Class }\end{array}$ \\
\hline 1 & 24 & Male & $\begin{array}{l}\text { Left sided } \\
\text { focal seizures, } \\
\text { followed by } \\
\text { todd's } \\
\text { paralysis } \\
\text { affecting left } \\
\text { side more in } \\
\text { the upper than } \\
\text { the than lower } \\
\text { limb }\end{array}$ & Parietal & Total & Extraaxial & Meningioma & 12 & $1 \mathrm{~A}$ & 29 & $1 \mathrm{~A}$ \\
\hline 2 & 48 & Male & $\begin{array}{l}\text { Right sided } \\
\text { focal seizures } \\
\text { affecting the } \\
\text { upper limb }\end{array}$ & Frontal & Total & Extraaxial & Meningioma & 9 & $1 \mathrm{~A}$ & 26 & $1 \mathrm{~A}$ \\
\hline 3 & 29 & Female & $\begin{array}{l}\text { Right sided } \\
\text { focal seizures }\end{array}$ & Parietal & Subtotal & Intraaxial & Infarction & 7 & 1B & 24 & $1 \mathrm{~A}$ \\
\hline 4 & 27 & Female & $\begin{array}{l}\text { Right hand } \\
\text { numbness at } \\
\text { age } 17 \text {, then } \\
\text { disappeared, } \\
\text { recurred once } \\
\text { every year } \\
\text { until one } \\
\text { attack passed } \\
\text { into } \\
\text { generalized } \\
\text { tonic clonic } \\
\text { seizures at } \\
\text { age } 27\end{array}$ & $\begin{array}{l}\text { Parieto } \\
\text { occipital }\end{array}$ & Subtotal & Extraaxial & AVM & 9 & 1B & 26 & $2 \mathrm{~A}$ \\
\hline 5 & 18 & Male & $\begin{array}{l}\text { Right focal } \\
\text { seizures with } \\
\text { secondary } \\
\text { generalization }\end{array}$ & Frontal & Total & Intraaxial & $\begin{array}{l}\text { Low Grade Glioma } \\
\text { (astrocytoma } \\
\text { grade 2) }\end{array}$ & 13 & 1D & Lost & Lost \\
\hline 6 & 50 & Female & $\begin{array}{l}\text { Left focal } \\
\text { seizures with } \\
\text { secondary } \\
\text { generalization }\end{array}$ & Frontal & Total & Extraaxial & Meningioma & 8 & $1 \mathrm{~A}$ & 25 & 1B \\
\hline 7 & 40 & Female & $\begin{array}{l}\text { Right focal } \\
\text { seizures with } \\
\text { secondary } \\
\text { generalization, } \\
\text { associated } \\
\text { with visual } \\
\text { hallucinations }\end{array}$ & Parietal & Total & Intraaxial & Cavernoma & 7 & $1 \mathrm{~A}$ & 24 & $3 B$ \\
\hline 8 & 46 & Female & $\begin{array}{l}\text { Right focal } \\
\text { seizures with } \\
\text { secondary } \\
\text { generalization }\end{array}$ & Frontal & Total & Extraaxial & Meningioma & 6 & 1D & 23 & $1 \mathrm{~A}$ \\
\hline 9 & 64 & Male & $\begin{array}{l}\text { Left sided } \\
\text { focal seizures } \\
\text { with } \\
\text { secondary } \\
\text { generalization }\end{array}$ & Frontal & Total & Extraaxial & Meningioma & 9 & $1 \mathrm{~A}$ & 26 & $1 \mathrm{~A}$ \\
\hline 10 & 60 & Female & $\begin{array}{l}\text { Left focal } \\
\text { seizures with } \\
\text { secondary } \\
\text { generalization }\end{array}$ & Parietal & Total & Extraaxial & Meningioma & 5 & $1 \mathrm{~A}$ & 22 & $1 \mathrm{~A}$ \\
\hline 11 & 33 & Female & $\begin{array}{l}\text { Left sided } \\
\text { focal seizures } \\
\text { with } \\
\text { secondary } \\
\text { generalization }\end{array}$ & Frontal & Total & Intraaxial & $\begin{array}{l}\text { Low Grade Glioma } \\
\text { (astrocytoma grade } \\
\text { 2) }\end{array}$ & 3 & $1 \mathrm{~A}$ & Lost & Lost \\
\hline
\end{tabular}




\begin{tabular}{|c|c|c|c|c|c|c|c|c|c|c|c|}
\hline Number & Age & Gender & $\begin{array}{l}\text { Clinical } \\
\text { presentation }\end{array}$ & $\begin{array}{l}\text { Anatomical } \\
\text { location }\end{array}$ & $\begin{array}{l}\text { Extent of } \\
\text { lesionectomy }\end{array}$ & $\begin{array}{l}\text { Relation to } \\
\text { cerebral } \\
\text { parenchyma }\end{array}$ & Histopathology & $\begin{array}{l}\text { Short } \\
\text { Term } \\
\text { Follow } \\
\text { UP in } \\
\text { Months }\end{array}$ & $\begin{array}{l}\text { Short } \\
\text { Term } \\
\text { Follow } \\
\text { UP } \\
\text { Engels' } \\
\text { Class }\end{array}$ & $\begin{array}{l}\text { Long } \\
\text { Term } \\
\text { Follow } \\
\text { UP in } \\
\text { months }\end{array}$ & $\begin{array}{l}\text { Long } \\
\text { Follo' } \\
\text { Enge } \\
\text { Class }\end{array}$ \\
\hline 12 & 37 & Male & $\begin{array}{l}\text { Right focal } \\
\text { seizures with } \\
\text { secondary } \\
\text { generalization }\end{array}$ & Frontal & Total & Intraaxial & $\begin{array}{l}\text { Low Grade Glioma } \\
\text { (ependymoma } \\
\text { grade 2) }\end{array}$ & 4 & $1 \mathrm{D}$ & 21 & $4 \mathrm{~A}$ \\
\hline 13 & 26 & Female & $\begin{array}{l}\text { Left focal } \\
\text { seizures with } \\
\text { secondary } \\
\text { generalization }\end{array}$ & Frontal & $\begin{array}{l}\text { Total with } \\
\text { safety } \\
\text { margin }\end{array}$ & Intraaxial & $\begin{array}{l}\text { Low Grade Glioma } \\
\text { (oligodendrolioma } \\
\text { grade 2) }\end{array}$ & 6 & $1 \mathrm{~A}$ & 23 & $1 \mathrm{~A}$ \\
\hline 14 & 50 & Female & $\begin{array}{l}\text { Left focal } \\
\text { seizures with } \\
\text { secondary } \\
\text { generalization }\end{array}$ & Frontal & Total & Extraaxial & Meningioma & 5 & $1 \mathrm{~A}$ & 22 & $1 \mathrm{~A}$ \\
\hline 15 & 50 & Male & $\begin{array}{l}\text { Right focal } \\
\text { seizures with } \\
\text { secondary } \\
\text { generalization }\end{array}$ & Parietal & Total & Extraaxial & Meningioma & 9 & $1 \mathrm{~B}$ & 20 & $\begin{array}{l}\text { Died } \\
3 \text { tim } \\
\text { recurı } \\
\text { reope } \\
\text { deteri } \\
\text { and }\end{array}$ \\
\hline 16 & 28 & Male & $\begin{array}{l}\text { Left focal } \\
\text { seizures }\end{array}$ & Parietal & Total & Intraaxial & $\begin{array}{l}\text { Low Grade Glioma } \\
\text { (astrocytoma grade } \\
\text { 2) }\end{array}$ & 3 & $1 \mathrm{~A}$ & Lost & Lost \\
\hline 17 & 55 & Male & $\begin{array}{l}\text { Right focal } \\
\text { seizures with } \\
\text { secondary } \\
\text { generalization }\end{array}$ & Occipital & Total & Extraaxial & $\begin{array}{l}\text { Plasma Cell } \\
\text { Myeloma }\end{array}$ & 4 & $1 \mathrm{D}$ & 21 & $4 \mathrm{~A}$ \\
\hline 18 & 25 & Male & $\begin{array}{l}\text { Headache } \\
\text { followed by } \\
\text { generalization } \\
\text { in the form of } \\
\text { ( absence), } \\
\text { followed by } \\
\text { fatigue for } 30 \\
\text { minutes }\end{array}$ & Frontal & Total & Intraaxial & $\begin{array}{l}\text { Low Grade Glioma } \\
\text { (subependymoma } \\
\text { grade 2) }\end{array}$ & 4 & $1 \mathrm{~A}$ & 21 & $1 \mathrm{~A}$ \\
\hline 19 & 40 & Female & $\begin{array}{l}\text { Aphasia } \\
\text { followed by } \\
\text { memory } \\
\text { disturbance. }\end{array}$ & Frontal & Total & Extraaxial & Meningioma & 3 & $1 \mathrm{~A}$ & 20 & $1 \mathrm{D}$ \\
\hline 20 & 33 & Female & $\begin{array}{l}\text { Right focal } \\
\text { seizures. }\end{array}$ & Frontal & $\begin{array}{l}\text { Total with } \\
\text { safety } \\
\text { margin }\end{array}$ & Intraaxial & $\begin{array}{l}\text { Low Grade Glioma } \\
\text { (Oligodendroglioma } \\
\text { grade 2) }\end{array}$ & 3 & $1 \mathrm{~A}$ & Lost & Lost \\
\hline
\end{tabular}

Preoperative evaluation with proper history taking, clinical examination and MRI brain for all the included patients was done to show the lesions and ensure concordance of clinical semiology and lesional lateralization. Scalp EEG was done using the international 10-20 system. For all of the patients, surgery was done under general anesthesia. No awake craniotomy was done for any of the patients and intraoperative functional mapping and electrophysiological monitoring were not used due to paucity of resources. Surgical procedures were categorized into: Subtotal excision, Total excision and Total excision with safety margin (2-3 mm peri-lesional). Intra-operative complications were recorded if present. Post-operative CT brain was done for all patients and histopathological examination of the excised lesional specimens was done and the nature of the lesions were recorded. Post-operative MRI was done during the follow up period to confirm the extent of surgical excision.

After discharge, the patients were followed up clinically and radiologically. They were assessed for their seizure outcome according to Engel's classification[4] Clinical assessment for any deficit was recorded. During the follow up, four patients were lost, so we decided to provide our results stratified into a short term follow up period including all the 20 patients, and a long term follow up period including only the remaining 16 patients.

\section{Statistical analysis:}

During data analysis we aimed to show the effect of lesional factors on seizure outcome. Lesional factors included: the anatomical location of the lesion (frontal, parietal, occipital, parieto-occipital), the relation of the lesion to cerebral parenchyma (intra-axial, extra-axial), the extent of surgical excision (subtotal, total, total with safety margin) and the histopathological nature of the lesion. Microsoft excel 2013 (Microsoft Corporation, Redmond, Washington, USA) was used for data entry and the statistical package for social science (SPSS) version 22 (International Business Machines Corporation (IBM), Armonk, New York, USA) was used for data analysis.

\section{Results}


Twenty patients were included, nine males (45\%) and eleven females (55\%). Age ranged from 18 to 64 (mean age 39.15 years). The short follow up period ranged between 3 months and 13 months with a mean follow up period of 6.45 months, while the long follow up period ranged between 20 months and 29 months (mean 23.31 months) for 16 patients, excluding four patients who were lost in follow up.

\section{Lesional Factors}

The lesions were located in the frontal lobe in 12 patients (60\%), parietal lobe in six patients (30\%), pareito-occipital in one patient (5\%) and occipital bony lesion in one patient (5\%). Eleven patients (55\%) had extra-axial lesions, while nine patients (45\%) had intra-axial lesions. Subtotal excision was done in two patients (10\%) (AVM, infarction). For the AVM patient, surgery was stopped to avoid excessive uncontrollable bleeding threatening the hemodynamic stability, while for the patient with infarction, subtotal resection was done to avoid any neurological deficits. Total excision was carried out for 16 patients (80\%) including nine meningiomas, one cavernoma, three astrocytoma grade 2 , one subependymoma, one ependymoma and one plasma cell myeloma. Total excision with safety margin (2-3 mm peri-lesional) was done in two patients (10\%), both had oligodendroglioma (Table 2 ).

Table 2

Lesional factors

\begin{tabular}{|c|c|c|c|}
\hline & & Frequency & Percent \\
\hline \multirow[t]{4}{*}{ Anatomical location } & Frontal & 12 & 60.0 \\
\hline & Occipital & 1 & 5.0 \\
\hline & Parietal & 6 & 30.0 \\
\hline & Parieto occipital & 1 & 5.0 \\
\hline \multirow[t]{3}{*}{ Extent of Lesionectomy } & Subtotal & 2 & 10.0 \\
\hline & Total & 16 & 80.0 \\
\hline & Total with safety margin & 2 & 10.0 \\
\hline \multirow[t]{2}{*}{ Relation to cerebral parenchyma } & Extraaxial & 11 & 55.0 \\
\hline & Intraaxial & 9 & 45.0 \\
\hline \multirow[t]{6}{*}{ Histopathology } & AVM & 1 & 5.0 \\
\hline & Cavemoma & 1 & 5.0 \\
\hline & Infarction & 1 & 5.0 \\
\hline & Low Grade Glioma & 7 & 35.0 \\
\hline & Meningioma & 9 & 45.0 \\
\hline & Plasma Cell Myeloma & 1 & 5.0 \\
\hline
\end{tabular}

Histopathological examination confirmed the lesional pathologies as follows (Fig. 1):

- Nine intra-axial lesions (45\%): seven low grade gliomas including: three astrocytoma G2, two oligodendroglioma, one ependymoma, and one subependymoma. They represented $78 \%$ of intra-axial lesions and $35 \%$ of all lesions. The other two lesions were one infarction and one cavernoma representing $22 \%$ of intra-axial lesions.

- Eleven extra-axial lesions (55\%): nine meningiomas (82\% of extra-axial lesions, $45 \%$ of all lesions). The other two lesions (18\% of extra-axial lesions) were one AVM and one case of plasma cell myeloma (occipital bony lesion).

It's to be noted that among the 20 patients, 17 had tumors (85\%), while three (15\%) had non tumoral lesions (Cavernoma, AVM, Infarction).

Out of these twenty patients, four had post-operative complications (20\%). Two patients had motor weakness, one patient had mild facial palsy and one patient had dysphasia.

\section{Seizure outcome}

For the 20 patients included, post-operative seizure outcome at the last follow up visit according to Engel's classification was as follows:

\section{Short term follow up (mean 6.45 months)}

All of the 20 patients were seizure free with Engel's class 1 (100\%).

\section{Patients lost in follow up}

Four patients (20\%) were lost in follow up, all of them were patients with low grade gliomas including three astrocytomas and one oligodendroglioma.

Long term follow up (mean 23.31 months) 
Sixteen patients were available for 20 months follow up or more. Of them, 11 patients $(68.75 \%)$ were seizure free with Engel's class 1 , while five patients had worse outcomes (31.25\%) (Table 3). One of those five patients had a meningioma that recurred and was re-operated three times, then gradually deteriorated until he passed away after 20 months of follow up. In four patients, seizures were not controlled including

Table 3

Seizure outcome

\begin{tabular}{|c|c|c|c|c|c|}
\hline & & & \multicolumn{2}{|c|}{ Seizure outcome (mean follow up 23.31 months) } & \multirow[t]{2}{*}{ Total } \\
\hline & & & Free (class 1) & Not Free (worse than class 1 or died) & \\
\hline \multirow[t]{2}{*}{ Total } & & Count & 11 & 5 & 16 \\
\hline & & $\%$ & $68.75 \%$ & $31.25 \%$ & $100.0 \%$ \\
\hline \multirow[t]{8}{*}{ Anatomical Location } & Frontal & Count & 8 & 1 & 9 \\
\hline & & $\%$ & $88.9 \%$ & $11.1 \%$ & $100.0 \%$ \\
\hline & Occipital & Count & 0 & 1 & 1 \\
\hline & & $\%$ & $0.0 \%$ & $100.0 \%$ & $100.0 \%$ \\
\hline & Parietal & Count & 3 & 2 & 5 \\
\hline & & $\%$ & $60.0 \%$ & $40.0 \%$ & $100.0 \%$ \\
\hline & Parieto occipital & Count & 0 & 1 & 1 \\
\hline & & $\%$ & $0.0 \%$ & $100.0 \%$ & $100.0 \%$ \\
\hline \multirow[t]{6}{*}{ Extent of Lesionectomy } & Subtotal & Count & 1 & 1 & 2 \\
\hline & & $\%$ & $50.0 \%$ & $50.0 \%$ & $100.0 \%$ \\
\hline & Total & Count & 9 & 4 & 13 \\
\hline & & $\%$ & $69.2 \%$ & $30.8 \%$ & $100.0 \%$ \\
\hline & Total with safety margin & Count & 1 & 0 & 1 \\
\hline & & $\%$ & $100.0 \%$ & $0.0 \%$ & $100.0 \%$ \\
\hline \multirow[t]{4}{*}{ Relation to cerebral parenchyma } & Extraaxial & Count & 8 & 3 & 11 \\
\hline & & $\%$ & $72.7 \%$ & $27.3 \%$ & $100.0 \%$ \\
\hline & Intraaxial & Count & 3 & 2 & 5 \\
\hline & & $\%$ & $60.0 \%$ & $40.0 \%$ & $100.0 \%$ \\
\hline \multirow[t]{12}{*}{ Histopathology } & AVM & Count & 0 & 1 & 1 \\
\hline & & $\%$ & $0.0 \%$ & $100.0 \%$ & $100.0 \%$ \\
\hline & Cavernoma & Count & 0 & 1 & 1 \\
\hline & & $\%$ & $0.0 \%$ & $100.0 \%$ & $100.0 \%$ \\
\hline & Infarction & Count & 1 & 0 & 1 \\
\hline & & $\%$ & $100.0 \%$ & $0.0 \%$ & $100.0 \%$ \\
\hline & Low Grade Glioma & Count & 2 & 1 & 3 \\
\hline & & $\%$ & $66.7 \%$ & $33.3 \%$ & $100.0 \%$ \\
\hline & Meningioma & Count & 8 & 1 & 9 \\
\hline & & $\%$ & $88.9 \%$ & $11.1 \%$ & $100.0 \%$ \\
\hline & Plasma Cell Myeloma & Count & 0 & 1 & 1 \\
\hline & & $\%$ & $0.0 \%$ & $100.0 \%$ & $100.0 \%$ \\
\hline
\end{tabular}

Parieto-occipital AVM, subtotal excision, class 2A.

Parietal cavernoma, total excision, class 3B.

Frontal low grade glioma (ependymoma grade 2), total excision, class 4A.

Occipital Plasma cell myeloma (of the occipital bone), total excision, class 4A. 


\section{Discussion}

We depended in our pre-operative evaluation on the cumulative data gathered through proper history taking, seizure semiology, clinical examination and lesional location on cerebral imagining. Surgery was done even if the EEG was non-contributory without further investigations such as invasive recording, electrocorticography or functional mapping due to paucity of resources as well as the presence of an obvious lesion on brain MRI that was concordant with seizure semiology,. The convergence of clinical and radiological evidence pointed to the lesion in all cases as being the most probable epileptogenic focus.

Our decision is reinforced by the study done by Roper et.al (2009) [5] that concluded that each test can be helpful in localizing the Epileptogenic zone in extratemporal epilepsy, but no single method is completely sensitive or specific and that's why the final decision making always depends on assessing concordant results from several different diagnostic modalities.[5] Similarly, Sandok and Cascino (1998)[6] clarified that the use of EEG before surgery depends on the planned surgical procedure and has variable results. $[6,7]$ Peri-operative and intraoperative functional mapping are less important in patients who are undergoing lesionectomy based on MRI.[6]

\section{Anatomical location}

In our series, most patients were found to have frontal lesions (12 patients, $60 \%$ ), followed by parietal lesions (Six patients, $30 \%$ ), and one patient with occipital lesion and another with parieto-occipital lesion (5\% each). This goes in line with literature as seizures are predominantly associated with lesions in the frontal or temporal lobe, insular regions as well as lesions in close relation to the cortex.[3, 8]

Within the follow up period (Mean 23.31 months), 4 patients were lost ( 3 frontal, 1 parietal). Of the remaining 16 patients, only 11 were seizure free with Engel's class 1 (68.75\%). Eight of nine patients with frontal lesions were seizure free (88.9\%), while 3 of 5 patients with parietal lesions were seizure free $(60 \%)$, one patient was not controlled, and one patient with convexity meningioma had three times recurrence and deteriorated and eventually died. The remaining two patients had occipital and Parieto-occipital lesions, and both were not seizure free.

Spencer and Huh (2008) [9] found that seizure freedom after extratemporal cortical resections reached up to $66 \%$ in children ( with higher proportion of lesional resections), and up to $76 \%$ in adults. The follow up period for studies included in their review was at least 1 year. Outcome of resective surgery to treat epilepsy in children differs from that in adults primarily because the syndromes amenable to surgery are much more heterogeneous.[9]

Similarly, Téllez-Zenteno and colleagues did a systematic review and meta-analysis about surgical outcome in lesional and non-lesional epilepsy [10]. The outcomes were reported after at least 1 year of follow-up. They found that seizure freedom in extratemporal lesional (LE) Epilepsy (MRI positive) is about 60 $\%$. These results are close to our results where $68.75 \%$ were seizure free within our follow up period (mean 23.31 months).

\section{Relation to cerebral parenchyma}

In addition to the anatomical location of the lesions, we found it of special interest to compare the intra-axial with the extra-axial lesions to evaluate the impact of the relation between the lesion and the cerebral parenchyma on seizure outcome after lesionectomy. It's known that both intra-axial and extra-axial brain tumors may be associated with seizures (Rajneesh and Binder 2009). [11] Although in cases with intra-axial lesions the epileptogenic zone might be included within, around, or far from the lesional zone, the simple lesionectomy still have a chance of resecting the epileptogenic zone if it was in close relation to the lesional zone. In extra-axial lesions, however, the lesions are excised without dealing with the previously compressed, edematous or irritated cortex, or in other words, the epileptogenic zone is not resected. The pathophysiology of seizures with extra-axial lesions, such as meningiomas, is assumed to be caused by the combined effect of the of tumor mass effect on epileptogenic cortex, acid/base derangements from cerebral edema, and/or disturbances of neurotransmitter pathways (Chaichana et al. 2013).[12] Therefore, seizures with extra-axial lesions might need further management in addition to simple lesionectomy. During our follow up period (mean 23.31 months), eight out of 11 patients with extra-axial lesions (72.7\%) were seizure free, while three out of five patients with intra-axial lesions (60\%) were seizure free. Although we couldn't record a significant statistical difference in seizure outcome between intraaxial and extra-axial lesions (P value 0.611 ), we still highly recommend a further study on a larger scale and longer follow up period to get a strong evidence based conclusion regarding the difference in epilepsy outcome between intra-axial and extra-axial lesions.

\section{Histopathology}

The most common pathology encountered in our series was low grade glioma for intra-axial lesions and meningioma for extra-axial lesions. Among nine intraaxial lesions, seven (78\%) were found to be low grade gliomas, of which three were astrocytoma WHO Grade 2, two oligodendroglioma, one ependymoma and one sub-ependymoma. The other two intra-axial lesions (22\%) were infarction and cavernoma.

During the long follow up period, 4 patients with low grade gliomas were lost, leaving 5 patients with intra-axial lesions including three patients with low grade gliomas of which two were seizure free with Engel's Class 1 (oligodendroglioma grade 2, and subependymoma grade 2), and one was not free with Engel's class 4 (ependymoma grade 2). The remaining two patients were the patient with infarction that was seizure free with Engel's class 1 , and the cavernoma patient that was not seizure free with Engel's Class 3.

Although we operated on the infarction patient erroneously thinking it was a tumor, yet there is evidence in literature to suggest that a focal ischemic or hemorrhagic event may result in the formation of gliotic tissue within the atrophic brain lesion (encephalomalacia), that present with intractable seizures.[13] Ghatan et al 2014 [14] evaluated surgical management of medically refractory epilepsy due to early childhood stroke and concluded that epilepsy surgery is effective in controlling medically intractable seizures after perinatal vascular insults.[14]

In addition to the intra-axial lesions, we had 11 patients with extra-axial lesions including nine meningiomas (82\%) of which eight were seizure free Engel's Class $1(88.9 \%)$, the other two patients (18\%) had AVM and plasma cell myeloma of the occipital bone and both were not seizure free. These results matches 
what was found in previous studies about the most common pathologies to present with seizures, but due to the few number of each pathology in our series, we found that it would be inaccurate to compare our results for each individual pathology with the studies that focus on one pathological type and its seizure outcome. We could, however, show the number of meningiomas, and low grade gliomas (grouped together) to allow us to do such comparison.

Lynam et al (2007) [15] showed that the patients with primary CNS tumor more commonly presenting with seizures were found to have low grade Gliomas. Rajneesh and Binder (2009)[11] had similar results. Likewise, Tandon and Esquenazi (2013)[3] studied a series of tumor related epilepsy and the most common tumors in their group included low-grade gliomas and GNTs (glioneuronal tumors) including both temporal and extratemporal locations.

Chaichana et al. 2013[12] evaluated seizure control for patients undergoing meningioma surgery and found that among patients who presented with seizures, the majority remained seizure free. They related poor seizure control to factors such as uncontrolled preoperative seizures, parasagittal/ parafalcine tumors, and sphenoid wing tumors. [12] We had nine meningiomas, eight of them were seizure free with Engel's Class 1, while one patient had three times recurrence until he deteriorated and died after 20 months.

\section{Extent of surgical resection:}

Despite the variability of the lesions included in our study regarding their exact anatomical location, their relation to the cerebral parenchyma or even their histopathological nature, lesionectomy was successful to guarantee a satisfactory outcome with Engel's Class 1 in $68.75 \%$ of cases during the follow up period (Mean 23.31 months). Only two patients had subtotal resection (AVM and infarction). The patient with infarction is seizure free with Engel's Class 1, while the patient with AVM is not seizure free with Engel's Class 2. Sixteen patients underwent total resection of which three were lost in follow up, nine are seizure free with Engel's Class 1, and four are not seizure free. Two cases were operated upon by total resection with safety margin (both were oligodendrioglioma), one of them was lost in follow up, while the other is seizure free with Engel's class 1.

Although we achieved seizure freedom in $68.75 \%$ of our cases, it should be emphasized that most of the lesions in our series were tumors ( 13 cases out of 16 $(81.25 \%)$ ) and the fact that we didn't have any case of focal cortical dysplasia or gliosis or other non tumoral lesions apart from three cases with AVM, Cavernoma and infarction in our series. It was found significant to mention the results of previous studies regarding focal cortical dysplasia as it has the poorest outcome of lesional epilepsy [5], and since we didn't have such cases with known poor outcome, it is necessary to be clarified.

Our results are strongly aligned with the results of previous studies that evaluated seizure control after lesionectomy for extratemporal tumors. Tandon and Esquenazi (2013)[3] concluded that initial aggressive tumor resection yielded Engel's Class 1 in all of the patients in their study except for the cases with tumor residual or tumor recurrence [3]. Sandok and Cascino (1998) [6] evaluated the surgical treatment for perirolandic lesional epilepsy and Engel's Class 1 was found in 13 of 14 cases (93\%).[6] Elsharkawy et al. (2008) [16] reviewed Long-term outcome of extratemporal epilepsy surgery among 154 adult patients. In reviewing seizure outcome in relation to pathological findings, $93.8 \%$ of their patients with neoplastic lesions had favorable outcomes after surgery, which dropped to $56 \%$ after 14 years of follow up (Engel's class 1 ).

The results of these studies are closer to what we found in our series than other studies that included all tumoral and non tumoral lesions and justify the good results of our lesionectomies being related mostly to the tumoral nature and total resection.

\section{Limitations}

The paucity of resources limited our perioperative neurophysiological work up. However, we could rely on concordant evidence of MRI and seizure semiology. Moreover, the lack of a database documenting all the cases presenting with seizures prevented us from including cases on a retrospective manner, and limited our overall number of cases, with which we couldn't withdraw data of statistical significance. We could, however, compare our results with those of literature to validate our current practice.

\section{Conclusions}

In a country with limited resources, lesionectomy is a valid technique for epilepsy surgery as long as the radiological data and the seizure semiology are concordant.

While reviewing the literature, we concluded that extratemporal lesional epilepsy is caused by either neoplastic or non-neoplastic lesions. The frontal lobe is the most frequent location in patients presenting with lesional extratemporal epilepsy. Both intra-axial and extra-axial lesions can present with seizures as the first presenting symptom, the most frequent being low grade gliomas and meningiomas. Total lesionectomy provides a good chance for seizure control when the clinical and radiological data are concordant with seizure semiology, in particular with tumor-related epilepsy. We are strongly recommending a study comparing post-operative seizure outcome between intra-axial and extra-axial lesions on a larger scale and with a longer follow up period to show which patients may benefit further epilepsy surgery such as cortical resections or multiple subpial transections, especially in the extra-axial group.

\section{Abbreviations}

CT: Computed tomography

EEG: Electroencephalogram

MRI: Magnetic resonance imaging

\section{Declarations}


Ethics approval and consent to participate:

All procedures performed in this study were in accordance with the ethical standards of the ethical committee of the Neurosurgery Department in our institute and with the 1964 Helsinki declaration and its later amendments or comparable ethical standards.

Informed consent was obtained from all individual participants included in the study.

\section{Consent for publication:}

Not applicable.

\section{Availability of data and materials:}

Data sharing is not applicable to this article as no datasets were generated or analysed during the current study.

\section{Competing interests}

The authors declare that they have no competing interests

\section{Funding:}

The authors report no involvement in the research by the sponsor that could have influenced the outcome of this work.

\section{Authors' contributions:}

Dr. Amr Ali Hasanain collected and analyzed the data and wrote the manuscript.

Prof. Mohamed Sawan and Prof.Ahmed Ali supervised the study and revised the manuscript.

All authors read and approved the final manuscript.

\section{Acknowledgements:}

Not applicable

\section{References}

1. Youmans JR, Winn HR. Youmans neurological surgery. [Internet]. Philadelphia: Elsevier/Saunders; 2011 [cited 2019 Jun 12]. Available from: http://search.ebscohost.com/login.aspx?direct=true\&scope=site\&db=nlebk\&db=nlabk\&AN=445125

2. Giulioni M, Marucci G, Martinoni M, Marliani AF, Toni F, Bartiromo F, et al. Epilepsy associated tumors: Review article. World J Clin Cases. 2014 ;2:623-41.

3. Tandon N, Esquenazi Y. Resection strategies in tumoral epilepsy: is a lesionectomy enough? Epilepsia. 2013;54 Suppl 9:72-8.

4. West S, Nolan SJ, Cotton J, Gandhi S, Weston J, Sudan A, et al. Surgery for epilepsy. Cochrane Database Syst Rev. $2015 ;$ CD010541.

5. Roper SN. Surgical treatment of the extratemporal epilepsies. Epilepsia. 2009;50 Suppl 8:69-74.

6. Sandok EK, Cascino GD. Surgical treatment for perirolandic lesional epilepsy. Epilepsia. 1998;39 Suppl 4:S42-48.

7. Cascino GD, Hulihan JF, Sharbrough FW, Kelly PJ. Parietal lobe lesional epilepsy: electroclinical correlation and operative outcome. Epilepsia. 1993;34:5227.

8. Chang EF, Potts MB, Keles GE, Lamborn KR, Chang SM, Barbaro NM, et al. Seizure characteristics and control following resection in 332 patients with lowgrade gliomas. J Neurosurg. 2008;108:227-35.

9. Spencer S, Huh L. Outcomes of epilepsy surgery in adults and children. Lancet Neurol. 2008;7:525-37.

10. Téllez-Zenteno JF, Hernández Ronquillo L, Moien-Afshari F, Wiebe S. Surgical outcomes in lesional and non-lesional epilepsy: a systematic review and meta-analysis. Epilepsy Res. 2010;89:310-8.

11. Rajneesh KF, Binder DK. Tumor-associated epilepsy. Neurosurg Focus. 2009;27:E4.

12. Chaichana KL, Pendleton C, Zaidi H, Olivi A, Weingart JD, Gallia GL, et al. Seizure control for patients undergoing meningioma surgery. World Neurosurg. 2013;79:515-24.

13. Bennett-Back O, Ochi A, Widjaja E, Nambu S, Kamiya A, Go C, et al. Magnetoencephalography helps delineate the extent of the epileptogenic zone for surgical planning in children with intractable epilepsy due to porencephalic cyst/encephalomalacia. J Neurosurg Pediatr. 2014;14:271-8. 
14. Ghatan S, McGoldrick P, Palmese C, La Vega-Talbott M, Kang H, Kokoszka MA, et al. Surgical management of medically refractory epilepsy due to early childhood stroke. J Neurosurg Pediatr. 2014;14:58-67.

15. Lynam LM, Lyons MK, Drazkowski JF, Sirven Jl, Noe KH, Zimmerman RS, et al. Frequency of seizures in patients with newly diagnosed brain tumors: a retrospective review. Clin Neurol Neurosurg. 2007;109:634-8.

16. Elsharkawy AE, Behne F, Oppel F, Pannek H, Schulz R, Hoppe M, et al. Long-term outcome of extratemporal epilepsy surgery among 154 adult patients. J Neurosurg. 2008;108:676-86.

\section{Figures}

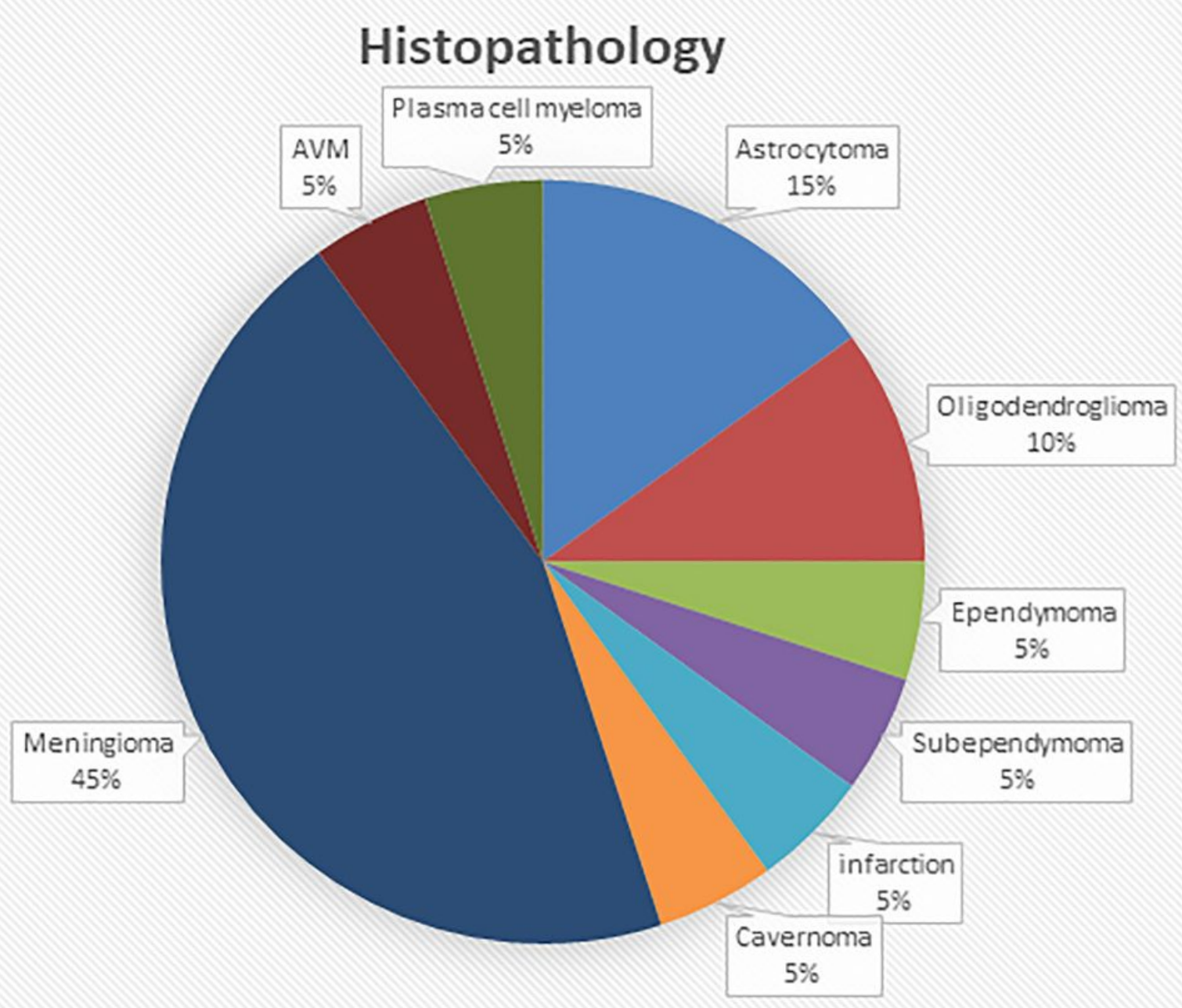

Figure 1

Histopathology of all patients in percentage form. 